\title{
Potential Use of Polysaccharides from the Brown Alga Undaria pinnatifida as Anticoagulants
}

\author{
Caterina Faggio $^{1}$, Marina Morabito ${ }^{1 *}$, Simona Armeli Minicante ${ }^{2}$, Giada Lo Piano ${ }^{1}$, Maria \\ Pagano $^{1}$ and Giuseppa Genovese ${ }^{1}$ \\ ${ }^{1}$ Department of Biological and Environmental Sciences; University of Messina; Messina - Italy. ${ }^{2}$ Department of \\ Environmental Sciences, Informatics and Statistics; University Ca' Foscari; Venezia - Italy
}

\begin{abstract}
Undaria pinnatifida (U. pinnatifida) is a highly invasive species and has caused concern all over the world because it has invaded coastal environments, has the potential to displace native species, significantly alters habitat for associated fauna, and disturbs navigation. Any attempt to eradicate it would be futile, owing to the elusive, microscopic gametophyte, and because the alga thrives in sites rich in anthropic activities. Venice Lagoon is the largest Mediterranean transitional environment and the spot of the highest introduction of non-indigenous species, including U. pinnatifida, which is removed as a waste. We demonstrated that polysaccharide extracts from U. pinnatifida have an anticoagulant effect on human blood in vitro and are not cytotoxic. The results obtained by PT (normal values 70-120\%) and APTT (normal values 28-40s) assays were significantly prolonged by the polysaccharide extracts of U. pinnatifida, therefore algal extracts are ideal candidates as antithrombotic agents.
\end{abstract}

Key words: Algal extract, anticoagulant activity, cytotoxicity, fucoidans, human blood cells, Undaria pinnatifida

\section{INTRODUCTION}

Venice Lagoon is located along the northwest coast of the Adriatic Sea and is the largest Mediterranean transitional environment (about 550 $\mathrm{km}^{2}$ ) with its unique ecology. Because of the intense human activities it is also the spot of the highest introduction of non-indigenous species. Among these, the brown alga Undaria pinnatifida (Harvey) Suringar (Phaeophyceae) was detected for the first time in the 1990s (Rismondo et al. 1993) and have gradually colonized most of the hard substrates, becoming the most important species for cover and biomass on the banks of canals (Curiel and Marzocchi 2010).

$U$. pinnatifida is a highly invasive species, classified as one of the top 100 global invasive species, and has caused concern all over the world as it has invaded the coastal environment in parts of Europe, Australia, New Zealand, Argentina and the USA (Hunt et al. 2009). Although published evidences of ecological impacts are equivocal (Forrest and Taylor 2002), recent studies suggest that Undaria has the potential to displace native seaweed species and significantly alters habitat for associated fauna including commercial species like abalone (Haliotis iris) and sea urchins (Evechinus chloroticus) (Curiel et al. 2002, Silva et al. 2002, Valintine and Johnson 2003, Casas et al. 2004).

There are concerns that Undaria could have also economic impacts on the aquaculture industry, because of the potential fouling risks to mussel and fish farms resulting in increased harvesting costs and farm maintenance (Hunt et al. 2009). In European countries (France, England) and North America (Washington State, California), the

\footnotetext{
*Author for correspondence: morabitom@unime.it
} 
problem of invasive algae threatening biodiversity has been addressed with a multidisciplinary approach based on a series of operations for the eradication, including mechanical (with tractors or pontoons) or manual, chemical (herbicides) or biological (herbivores) treatments, without success (Gray and Jones 1977, Lewey and Jones 1977, Loraine 1989, Belsher 1991, Davison 1996).

The eradication in Venice Lagoon does not appear easy to implement mainly because the colonization is established over several years and also due to the complexity of the sites, which are strongly related to anthropic activities and economic structures or public utilities (docks, piers, pipes and cables buried under piles of wood or concrete) (Curiel and Marzocchi 2010).

Moreover, there are observations on Australian established populations that any attempt to eradicate it would be futile (Brown and Lamare 1994), owing to the elusive, microscopic gametophyte stage of the alga (Sanderson 1990).

However, in original Indo-Pacific regions, Undaria plays an important role in the local economy and its biomass is particularly exploited on a global industry.

It is a popular food source in Japan, Korea and China where the market is worth about $\$ 400$ million (Barratt-Boyes 2012). Scientists are researching the commercial applications of Undaria as nutraceutical, drug, fertilizer or fish food, and are also exploring new market opportunities.

Undaria pinnatifida is one of the most utilized brown alga in macrobiotic diet (Kolb et al. 2004) and for the extraction of sulphonated polysaccharides, which represent a group of hydrocolloids from marine macroalgae (Camara et al. 2011, Jiao et al. 2011). They are structural components of the cell walls, partly responsible for the flexibility of the thalli (Laurienzo 2010). The most typical in brown algae are alginate, a polysaccharide of guluronic and mannuronic acids and fucans, a polysaccharide family rich in sulphated L-fucose. They differ in structure among algal species and even within the same species (Jiao et al. 2011) and may be present in the form of homopolymers or heteropolymers ( $\mathrm{Li}$ et al. 2008).

Recently, there has been increasing interest in the screening of bioactive compounds from natural sources, such as marine organisms (Vishchuk et al. 2011, Genovese et al. 2013). The literature reports a large diversity of biomedical activities associated with sulphated polysaccharides (Lahaye and Robic 2007, Assreuy et al. 2008, Pomin and Mourao 2008, Costa et al. 2010, Jiao et al. 2011,Wijesekara et al. 2011), such as antiviral (Ponce et al. 2003, Lee et al. 2004, Chattopadhyay et al. 2007), antioxidant (Rupérez et al. 2002), anticancer, anti-inflammation (Noda et al. 1990, Berteau and Mulloy 2003, Na et al. 2010, Magalhaes et al. 2011), and anticoagulant (Li et al. 2008, Faggio et al. 2014). After the investigation of blood anticoagulant properties from marine brown algae (Killing 1913), it has been reported that sulphated polysaccharides derived from seaweeds are alternative sources for the manufacture of novel anticoagulants (Church et al. 1989, Carlucci et al. 1997, Mao et al. 2006, Barroso et al. 2008, Nishino et al. 2000, Matsubara 2004, Mao et al. 2009, Costa et al. 2010, Camara et al. 2011, Mestechkina and Shcherbukhin 2010, Magalhaes et al. 2011).

The coagulation of blood is the third phase of haemostasis and is a process that intervenes to stop the bleeding in the event of major damage of the vessel wall. The primary pathway involves activation of platelets, the recruitment of von Willebrand factor (VWF) to promote platelet attachment to the site of injury, and the engagement of secondary haemostasis through various procoagulant proteins including fibrinogen, and factors (F) V and VIII (Lippi et al. 2009). Secondary haemostasis is also initiated directly by damage to the vasculature, primarily via the tissue factor pathway involving FVII, but also via the contact pathway, and as amplified by the primary pathway. In vitro, the tissue factor pathway and the contact pathway are respectively represented by the prothrombin time (PT) and activated partial thromboplastin time (APTT).

Various natural anticoagulants act moderating the secondary haemostasis pathway and preventing excessive procoagulant activity that may lead to a thrombosis or vascular occlusion. Therefore, primary haemostasis dysfunction leading to arterial thrombosis is usually managed using antiplatelet therapy (e.g., aspirin, glycoprotein IIb/IIIa inhibitors and ADP receptor/ P2Y12 inhibitors), whereas secondary haemostasis dysfunction leading to venous thrombosis is typically managed by anticoagulant therapy, classically unfractionated heparin (UH) or low molecular weight heparin (LMWH) (Casella et al. 2011, Favaloro et al. 2011, Casella et al. 2013). They are the drugs of choice in current clinical use 
when rapid effect is desired such as in intensive care setting, during surgery and for patients with renal failure. The current sources of heparin are animals, as it is obtained only from pig intestine or bovine lung. It is the second most frequently used natural drug but it has some disadvantages and it exhibits haemorrhagic-like side effects. Consequently, new research trends for the discovery of novel anticoagulant agents or of alternative sources of heparin are now an urgent need (Mourão and Pereira 1999, Shanmugam and Mody 2000).

Blood anticoagulant and antithrombotic properties have been reported for about 150 species of marine algae (Shanmugam and Mody 2000), mostly belonging to Phaeophyceae (McLellan and Jurd 1992, Irhimeh et al. 2009) in some cases superior to that of heparin (Springer et al. 1957, Kusaykin et al. 2008, Li et al. 2008, Pomin and Mourao 2008, Irhimeh et al. 2009). Unlike heparin, which produces a rapid but transient antithrombotic effect, the in vivo action of this sulphated galactofucan progressed slowly, showing maximal effectiveness about eight hours post injection.

The purpose of the present study was to suggest a possible use of $U$. pinnatifida, collected in Venice Lagoon (Italy), an invasive species of Indo-Pacific origin, as a potential source of bioactive molecules. In this topic we evaluated in vitro the anticoagulant activity of sulphated polysaccharides extracted from $U$. pinnatifida on human blood by means of the PT and APTT assays.

\section{MATERIAL AND METHODS}

\section{Polysaccharides extraction}

Undaria pinnatifida was collected in Venice Lagoon (Italy). Thalli were manually cleaned from debris and epiphytes using tap water, sun dried and milled to powder.

Powdered algae $(5 \mathrm{~g})$ were stirred with absolute ethanol for $1 \mathrm{~h}$ at $70^{\circ} \mathrm{C}$. The mixture was centrifuged at $4000 \times g$ for $10 \mathrm{~min}$ at room temperature. The pellet was treated with acetone for $1 \mathrm{~h}$ at room temperature, and the mixture was centrifuged at $4000 \times \mathrm{g}$ for $10 \mathrm{~min}$ at room temperature. Then, the pellet was dissolved in distilled water and allowed to stand for $24 \mathrm{~h}$ at $70^{\circ} \mathrm{C}$. After centrifugation $(4000 \times g$ for 10 minutes), polysaccharides were precipitated by adding $96 \%$ ethanol to the supernatant. The precipitate was collected and dried at room temperature. Algal extracts were dissolved in physiological solution $(0.9 \% \mathrm{NaCl})$ at $10 \mu \mathrm{g} / \mathrm{mL}$ and $20 \mu \mathrm{g} / \mathrm{mL}$.

\section{Haematological parameters}

Normal pooled blood from 15 individual healthy donors, without history of bleeding or thrombosis was collected. Blood samples were taken for haematological analysis. Plasma samples were obtained by centrifugation (1500xg for $15 \mathrm{~min}$ at room temperature). Haematological parameters included haemoglobin concentration, haematocrit, mean corpuscular volume (MCV), mean corpuscular haemoglobin concentration (MCHC), red cell distribution width (RDW), white blood cell count (WBC), red blood cell count (RBC), and were measured at the Blood Chemistry Laboratory Lo Piano in Villafranca Tirrena (Sicily, Italy) (Table 1).

\section{Trypan blue test}

In order to define cell viability, the whole blood samples were incubated for $30 \mathrm{~min}$ at room temperature in the saline solution described above containing both concentrations of algal extract (10 $\mu \mathrm{g} / \mathrm{mL}$ and $20 \mu \mathrm{g} / \mathrm{mL}$ ). Afterwards, $20 \mu \mathrm{L}$ of Trypan blue stock solution were added to $20 \mu \mathrm{L}$ of RBCs, hence they were loaded on a haemocytometer and examined immediately under a microscope at low magnification. The numbers of blue staining and total cells were counted. The percentage cell viability was calculated by the formula:

Cell viability $(\%)=\underline{\text { Number of viable cells (unstained cells) } \times 100}$ Total number of cells (stained and unstained)

\section{Anticoagulant activities}

The anticoagulant activities of all samples were investigated by the classical coagulation assays APTT and PT, using heparin as a reference.

Anticoagulant action measured by activated partial thromboplastin time (APTT). Activated partial thromboplastin time carried out with the standard kit (SGM Italy), on human blood samples were collected from fifteen healthy donators, were drawn into syringes filled with sodium citrate as an anticoagulant. In this assay, platelet-poor plasma sample $(0.1 \mathrm{~mL})$ were mixed with the different concentration of algal extracts $(0.01 \mathrm{~mL})$ in saline solution and warmed for $60 \mathrm{~s}$ at $37^{\circ} \mathrm{C}$ and then $0.1 \mathrm{~mL}$ pre-warmed APTT reagent was added and allowed to incubate for $3 \mathrm{~min}$ at $37^{\circ} \mathrm{C}$. Pre- 
warmed $0.025 \mathrm{M}$ calcium chloride $(0.1 \mathrm{~mL})$ was then added, and the APTT was recorded as the time for clot formation in a coagulant. All assays were performed in triplicate.

Anticoagulant action measured by prothrombin time $(P T)$. Prothrombin time was examined through the standard kit for prothrombin time determination (SGM Italy). Briefly, the reaction mixture containing both different concentration of algal extract $(0.01 \mathrm{~mL})$ in saline solution was incubated with $0.1 \mathrm{~mL}$ of plasma for $3 \mathrm{~min}$ at $37^{\circ} \mathrm{C}$, then $0.2 \mathrm{~mL}$ of pre-warmed PT reagent was added and the time for clot formation in a coagulant was recorded. All assays were performed in triplicate.

The protrombin time (PT) and activated partial thromboplastin time (APTT) coagulation assays were performed with a semiautomatic coagulometer (SEAC Clot 2) and measured using $3.2 \%$ citrate treated human plasma.

\section{Statistical analysis}

Statistical analyses were performed using Student's t-test. All calculations were carried out using Prism version 4.00 statistical software (GraphPad Software Inc., USA).

\section{RESULTS AND DISCUSSION}

No cytotoxic effect was observed on human red blood cells. Fucoidan administration caused no significant difference in haematological parameters (Table 1).

Table 1 - Complete blood count (CBC).

\begin{tabular}{|c|c|c|}
\hline Blood parameters & Men $n=7$ & Women $n=8$ \\
\hline Erythrocytes (RBC) $\left(x 10^{6} / \mu \mathrm{l}\right.$ blood) & $5.11 \pm 10.0$ & $4.51 \pm 10.0$ \\
\hline Haemoglobin $(\mathrm{Hb})(\mathrm{g} / 100 \mathrm{ml}$ blood $)$ & $16 \pm 0.01$ & $14 \pm 0.01$ \\
\hline Haematocrit (Het) (\%) & $46.0 \pm 1.0$ & $40.9 \pm 1.0$ \\
\hline Mean cell volume (MCV) ( $\mu \mathrm{m}^{3} /$ erythrocytes) & $90.1 \pm 1.0$ & $90.4 \pm 2.0$ \\
\hline Mean cell haemoglobin ( $\mathrm{MCH})(\mathrm{pg} /$ erythrocytes) & $30.2 \pm 0.01$ & $30.2 \pm 0.01$ \\
\hline $\begin{array}{l}\text { Mean corpuscular haemoglobin concentration }(\mathrm{MCHC})(\mathrm{g} / 100 \mathrm{ml} \\
\text { blood) }\end{array}$ & $34 \pm 0.01$ & $34 \pm 0.01$ \\
\hline 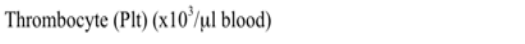 & $295 \pm 10.9$ & $295 \pm 10.8$ \\
\hline White Blood Cell Count (WBC) (x10 $0^{3} / \mu$ l blood) & $7.25 \pm 7.0$ & $7.28 \pm 7.8$ \\
\hline Lymphocytes (\%) & $32.5 \pm 1.5$ & $32.5 \pm 1.0$ \\
\hline Neutrophil granulocytes (\%) & $60 \pm 1.0$ & $60 \pm 1.2$ \\
\hline Eosinophil granulocytes (\%) & $5 \pm 1.1$ & $5 \pm 1.5$ \\
\hline Basophil granulocytes (\%) & $0.5 \pm 1.0$ & $0.5 \pm 1.0$ \\
\hline Monocytes (\%) & $2 \pm 1.0$ & $2 \pm 1.0$ \\
\hline
\end{tabular}

The results were showed in mean \pm standard deviation.
PT and APTT were significantly prolonged by the polysaccharide extracts of $U$. pinnatifida. Both tested concentrations $(10 \mu \mathrm{g} / \mathrm{mL}$ and $20 \mu \mathrm{g} / \mathrm{mL})$ showed PT $=1 \%$ and APTT $>100(\mathrm{~s})$.

The anticoagulant properties of the polysaccharide extracts are summarized in Table 2.

Table 2 - Anticoagulant activity of Undaria pinnatifida extract by PT and APTT assays.

\begin{tabular}{lcc}
\hline & PT (s) & APTT (s) \\
\hline Normal values & $9-15$ & $31-61$ \\
Heparin & 100 & 36.16 \\
$\begin{array}{l}\text { Undaria pinnatifida } \\
\text { extract }(10 \mathrm{mg} / \mathrm{ml})\end{array}$ & 1 & $>100$ \\
$\begin{array}{l}\text { Undaria pinnatifida } \\
\text { extract }(20 \mathrm{mg} / \mathrm{ml})\end{array}$ & 1 & $>100$ \\
\hline
\end{tabular}

Brown seaweeds are known to be not only important resources of food, feed and energy, but as also rich sources of polysaccharides with valuable biological activities, including alginate and sulphated polysaccharides (fucoidans) (Vishchuk et al. 2011). The composition of algal polysaccharides varies according to species, extraction procedure, season of harvest and local climatic conditions. Natural polysaccharides play a relevant role in biomedical and pharmaceutical applications, particularly in the field of drug delivery, for their intrinsic biocompatibility and potential low cost (Laurienzo 2010).

Probably, the most widely recognized and investigated bioactivity of marine sulphated polysaccharides is the heparin-like anticoagulant activity exhibited by fucans of brown seaweeds.

Heparin is the drug of the choice in the prevention of thromboembolic disorders, but recently alternative drugs for heparin are in high demand due to its bad and long-term side effects.

To overcome the obvious potential side-effect of bleeding, researchers have investigated means of reducing the anticoagulant activities of heparin while enhancing its anti-thrombotic activities including chemical modification and fractionation of native heparin to lower molecular forms (Jiao et al. 2011).

As an alternative source of anticoagulants, seaweed polysaccharides gained much attention in the pharmaceutical industry to develop better and safe drugs with low or less side effects (Athukorala et al. 2007, Laurienzo 2010, Mestechkina and Shcherbukhin 2010, Fitton 2011, Mayer et al. 2011, Wijesekara et al. 2011). The 
development of antithrombotic algal extracts would be advantageous also because their use would avoid the potential for contamination with prions or viruses in commercial heparins, which are obtained from animals. Moreover, with more specific activities and/or targets, the algal extracts having sulphated polysaccharides could find applications complementary to heparin.

In this study, we demonstrated that polysaccharide extracts of $U$. pinnatifida collected in Venice Lagoon have an anticoagulant effect prolonging coagulation time with respect to heparin. The results showed that prothrombin time (PT) and activated partial thromboplastin time (APTT) were effectively prolonged by the algal extracts. The prolongation of PT suggests that the extrinsic pathway of coagulation was inhibited, whereas the prolongation of APTT indicates the inhibition of the intrinsic and/or common pathway.

\section{CONCLUSIONS}

Over the last 15-20 years, numerous nonindigenous species have been found in Venice Lagoon (Curiel et al. 2006). Among these, $U$. pinnatifida produces a high biomass annually. Density, biomass and size of thalli of $U$. pinnatifida vary in different areas of Venice Lagoon depending on the chemical-physical and trophic characteristics of the water column. On average, density can be up to $400-450$ thalli $/ \mathrm{m}^{2}$ with biomass values of $5-10 \mathrm{~kg}$ fresh weight $/ \mathrm{m}^{2}$ (Curiel et al. 2002, Curiel et al. 2004), and fronds of about 1-2 m. An eradication intervention would not be applicable because the settlement is established over several years and also because the alga thrives in sites rich in anthropic activities (Curiel and Marzocchi 2010).

In New Zealand, conversely, the Ministry of Agriculture and Fisheries revised its policy to allow for greater commercial use of Undaria (Barratt-Boyes 2012). The general scope of the new regime includes: allowing Undaria to be farmed in certain heavily infested areas, and allowing it to be harvested when it is growing on artificial surfaces, when it has been cast ashore onto the beach or when part of a programme specifically designed to control Undaria.

At present, in Venice Lagoon $U$. pinnatifida is removed and processed as a waste, stocked in dumps and incinerated. According to a recent law (decree-law 217/2009), its use as a fertilizer in agriculture was allowed, but it is actually not practiced.

In conclusion, we propose a possible exploitation of $U$. pinnatifida thriving in Venice Lagoon as a source of anticoagulant drug with the aim of converting a waste into a valuable biomass.

\section{ACKNOWLEDGEMENTS}

A special acknowledgement is due to prof. Patrizia Torricelli, University Ca' Foscari Venezia, Italy, for her support during the research. This study was supported by a grant PRA 2005/2006 from the University of Messina to G.G.

\section{REFERENCES}

Assreuy AMS, Gomes DM, da Silva MSJ, Torres VM, Siqueira RCL, et al. 2008. Biological effects of a sulfated-polysaccharide isolated from the marine red algae Champia feldmannii. Biol Pharma Bull. 31: 691-695.

Athukorala Y, Lee K-W, Kim S-K, Jeon Y-J. 2007. Anticoagulant activity of marine green and brown algae collected from Jeju Island in Korea. Bioresource Technol. 98: 1711-1716.

Barratt-Boyes M. 2012. Pest may prove a source of plenty - Universities have several projects to commercialise Undaria. N Zeal Aquac. 46: 8-9.

Barroso EM, Costa LS, Medeiros VP, Cordeiro SL, Costa MS, et al. 2008. A non-anticoagulant heterofucan has antithrombotic activity in vivo. Planta Med.74: 712-718.

Belsher T. 1991. Sargassum muticum (Yendo) Fensholt sur le littoral français. Synthèse des actions enterprises de 1983 à 1989, IFREMER, Centre de Brest.

Berteau O, Mulloy B. 2003. Sulfated fucans, fresh perspectives: structures, functions, and biological properties of sulfated fucans and an overview of enzymes active toward this class of polysaccharide. Glycobiology 13: 29-40.

Brown M, Lamare M. 1994. The distribution of Undaria pinnatifida (Harvey) Suringar within Timaru Harbour, New Zealand. Jnp J Phycol. 42: 63-70.

Camara RBG, Costa LS, Fidelis GP, Nobre LTDB, Dantas-Santos N, et al. 2011. Heterofucans from the brown seaweed Canistrocarpus cervicornis with anticoagulant and antioxidant activities. Mar Drugs. 9: 124-138. 
Carlucci MJ, Pujol CA, Ciancia M, Noseda MD, Matulewicz MC, et al. 1997. Antiherpetic and anticoagulant properties of carrageenans from the red seaweed Gigartina skottsbergii and their cyclized derivatives: correlation between structure and biological activity. Int J Biol Macromol. 20: 97-105.

Casas G, Scrosati R, Piriz ML. 2004. The invasive kelp Undaria pinnatifida (Phaeophyceae, Laminariales) reduces native seaweed diversity in Nuevo Gulf (Patagonia, Argentina). Biol Inv. 6: 411-416.

Casella S, Giannetto C, Giudice E, Marafioti S, Fazio F, et al. 2013. ADP-induced platelet aggregation after addition of tramadol in vitro in fed and fasted horses plasma. Res Vet Sci. 94: 325-330.

Casella S, Giudice E, Giannetto C, Marafioti S, Piccione G. 2011. Effects of hydrocortisone and aminophylline on the aggregation of equine platelets in vitro. J Vet Sci. 12: 215-219.

Chattopadhyay K, Mateu CG, Mandal P, Pujol CA, Damonte EB, Ray B. 2007. Galactan sulfate of Grateloupia indica: Isolation, structural features and antiviral activity. Phytochemistry. 68: 1428-1435

Church F, Meade J, Treanor R, Whinna H. 1989. Antithrombin activity of fucoidan. The interaction of fucoidan with heparin cofactor II, antithrombin III, and thrombin. J Biol Chem. 264: 3618-3623.

Costa L, Fidelis G, Cordeiro S, Oliveira R, Sabry D, et al. 2010. Biological activities of sulfated polysaccharides from tropical seaweeds. Biomed Pharmacother. 64: 21-28.

Curiel D, Guidetti P, Bellemo G, Scattolin M, Marzocchi M. 2002. The introduced alga Undaria pinnatifida (Laminariales, Alariaceae) in the lagoon of Venice. Hydrobiologia. 477: 209-219.

Curiel D, Marzocchi M. 2010. Stato delle conoscenze nella laguna di Venezia di due alien species: Undaria pinnatifida e Sargassum muticum. Lavori - Soc Ven Sci Nat. 35: 93-106.

Curiel D, Rismondo A, Bellemo G, Marzocchi M. 2004. Macroalgal biomass and species variations in the Lagoon of Venice (Northern Adriatic Sea, Italy): 1981-1998. Sci Mar (Barc.). 68: 57-67.

Davison DM. 1996. Sargassum muticum in Strangford Lough, 1995 - 1998; A review of the introduction and colonisation of Strangford Lough MNR and cSAC by the invasive brown algae Sargassum muticum, Report to the Environment \& Heritage Service, D.o.E. (N.I.).

Faggio C, Pagano M, Morabito M, Minicante SA, Arfuso F, Genovese G. 2014. In vitro assessment of the effect of Undaria pinnatifida extracts on erythrocytes membrane integrity and blood coagulation parameters of Equus caballus. J Coast Lif Med. 2: 614-616.

Favaloro EJ, Lippi G, Koutts J. 2011. Laboratory testing of anticoagulants: the present and the future. Pathology.43: 682-92.
Fitton JH. 2011. Therapies from fucoidan; multifunctional marine polymers. Mar Drugs. 9: 1731-1760.

Forrest BM, Taylor MD. 2002. Assessing Invasion Impact: Survey Design Considerations and Implications for Management of An Invasive Marine Plant. Biol Inv. 4: 375-386.

Genovese G, Romeo O, Morabito M, Alessi D, Criseo G, Faggio C. 2013. Activity of ethanolic extracts of Asparagopsis taxiformis against the major molecular types of Cryptococcus neoformans/C. gattii complex. Afr J Microbiol Res. 7: 2662-2667.

Gray PWG, Jones EBG. 1977. The attempted clearance of Sargassum muticum from Britain. Envir Cor Serv. 4: 303-308.

Hunt L, Chadderton L, Stuart M, Cooper S, Carruthers M. 2009. Results of an attempt to control and eradicate Undaria pinnatifida in Southland, New Zealand, Department of Conservation Te Papa Atawahai, New Zealand Govenment .

Irhimeh MR, Fitton JH, Lowenthal RM. 2009. Pilot clinical study to evaluate the anticoagulant activity of fucoidan. Blood Coagul Fibrin. 20: 607-610.

Jiao G, Yu G, Zhang J, Ewart HS. 2011. Chemical Structures and Bioactivities of Sulfated Polysaccharides from Marine Algae. Mar Drugs. 9: 196-223.

Killing H. 1913. Zur biochemie der meersalgen. Z Physiol Chem. 83: 171-197.

Kolb N, Vallorani L, Milanovi N, Stocchi V. 2004. Evaluation of Marine Algae Wakame (Undaria pinnatifida) and Kombu (Laminaria digitata japonica) as Food Supplements. Food Technol Biotech. 42: 57-61.

Kusaykin M, Bakunina I, Sova V, Ermakova S, Kuznetsova T, et al. 2008. Structure, biological activity, and enzymatic transformation of fucoidans from the brown seaweeds. Biotechnol J. 3: 904-915.

Lahaye M, Robic A. 2007. Structure and Functional Properties of Ulvan, a Polysaccharide from Green Seaweeds. Biomacromolecules. 8: 1765-1774.

Laurienzo P. 2010. Marine Polysaccharides in Pharmaceutical Applications: An Overview. Mar Drugs. 8: 2435-2465.

Lee J-B, Hayashi K, Hashimoto M, Nakano T, Hayash T. 2004. Novel Antiviral Fucoidan from Sporophyll of Undaria pinnatifida (Mekabu). Chem. Pharm. Bull./ Tokyo 52: 1091-1094.

Lewey SA, Jones EBG. 1977. The effect of aquatic herbicides on selected marine algae. J Phycol. 12: 40

Li B, Lu F, Wei X, Zhao R. 2008. Fucoidan: structure and bioactivity. Molecules. 13: 1671-1695.

Lippi G, Favaloro EJ, Franchini M, Guidi GC. 2009. Milestones and perspectives in coagulation and hemostasis. Semin Thromb Hemost. 35: 9-22. 
Loraine I. 1989. L'algue japonaise Sargassum muticum (Yendo) Fensholt. Caractéristiques et répartition. Rapport. Archive Institutionnelle de l'Ifremer (http://archimer.ifremer.fr/doc/00000/1656/).

Magalhaes KD, Costa LS, Fidelis GP, Oliveira RM, Nobre LTDB, et al. 2011. Anticoagulant, antioxidant and antitumor activities of heterofucans from the seaweed Dictyopteris delicatula. International journal of molecular sciences. 12: 3352-3365.

Mao W, Li H, Li Y, Zhang H, Qi X, et al. 2009. Chemical characteristic and anticoagulant activity of the sulfated polysaccharide isolated from Monostroma latissimum (Chlorophyta). Int J Biol Macromol. 44: 70-74.

Mao W, Zang X, Li Y, Zhang H. 2006. Sulfated polysaccharides from marine green algae Ulva conglobata and their anticoagulant activity. J Appl Phycol. 18: 9-14.

Matsubara K. 2004. Recent advances in marine algal anticoagulants. Curr Med Chem Cardiovasc Hematol Agent. 2: 13-19.

Mayer A, Rodrìguez AD, Berlinck RGS, Fusetani N. 2011. Marine pharmacology in 2007-8: Marine compounds with antibacterial, anticoagulant, antifungal, anti-inflammatory, antimalarial, antiprotozoal, antituberculosis, and antiviral activities; affecting the immune and nervous system, and other miscellaneous mechanisms of action. Comp Biochem Physiol C Toxicol Pharmacol. 153: 191222.

McLellan DS, Jurd KM. 1992. Anticoagulants from marine algae. Blood Coagul Fibrinolysis. 3: 69-80.

Mestechkina N, Shcherbukhin V. 2010. Sulfated polysaccharides and their anticoagulant activity: A review. Appl Biochem Microbiol. 46: 267-273.

Mourão PAS, Pereira MS. 1999. Searching for Alternatives to Heparin: Sulfated Fucans from Marine Invertebrates. Trends Cardiovasc Med. 9: 225-332.

Na YS, Kim WJ, Kim SM, Park JK, Lee SM, et al. 2010. Purification, characterization and immunostimulating activity of water-soluble polysaccharide isolated from Capsosiphon fulvescens. Int immunopha. 10: 364-370.

Nishino T, Yamauchi T, Horie M, Nagumo T, Suzuki H. 2000. Effects of a fucoidan on the activation of plasminogen by u-PA and t-PA. Thromb Res. 99: 623-634.

Noda H, Amano H, Arashima K, Nisizawa K. 1990. Antitumor activity of marine algae. Hydrobiologia. 204: 577-584.
Pomin VH, Mourao PA. 2008. Structure, biology, evolution, and medical importance of sulfated fucans and galactans. Glycobiology.18: 1016-1027.

Ponce N, Pujol CA, Damonte EB, Flores MaL, Stortz CA. 2003. Fucoidans from the brown seaweed Adenocystis utricularis: extraction methods, antiviral activity and structural studies. Carbohyd Res. 338: 153-165.

Rismondo A, Volpe S, Curiel D, Solazzi A. 1993. Segnalazione di Undaria pinnatifida (Harvey) Suringar a Chioggia (Laguna Veneta). Lavori Soc Ven Na.t 18: 329-330.

Rupérez P, Ahrazem O, Leal JA. 2002. Potential Antioxidant Capacity of Sulfated Polysaccharides from the Edible Marine Brown Seaweed Fucus vesiculosus. Am Chem Soc. 50: 840-845.

Sanderson JC. 1990. A Preliminary Survey of the Distribution of the Introduced Macroalga, Undaria pinnatifida (Harvey) Suringer on the East Coast of Tasmania, Australia. In Botanica Marina, pp. 153

Shanmugam M, Mody KH. 2000. Heparinoid-active sulphated polysaccharides from marine algae as potential blood anticoagulant agents. Curr Sci. 79: 1672-1683.

Silva PC, Woodfield RA, Cohen AN, Harris LH, Goddard JHR. 2002. First report of the Asian kelp Undaria pinnatifida in the northeastern Pacific Ocean. Biol Inv. 4: 333-338.

Springer G, Wurzel H, McNeal G, Ansell N, GDoughty M. 1957. Isolation of anticoagulant fractions from crude fucoidin. Proc Soc Exp Biol Med. 94: 404-409.

Valintine JP, Johnson CR. 2003. Establishment of the introduced kelp Undaria pinnatifida in Tasmania depends on disturbance to native algal assemblages. $J$ Exp Mar Biol Ecol. 295: 63-90.

Vishchuk OS, Ermakova SP, Zvyagintseva TN. 2011. Sulfated polysaccharides from brown seaweeds Saccharina japonica and Undaria pinnatifida: isolation, structural characteristics, and antitumor activity. Carbohydr Res. 346:2769-2776.

Wijesekara I, Pangestuti R, Kim S-K. 2011. Biological activities and potential health benefits of sulfated polysaccharides derived from marine algae. Carbohyd Polym. 84: 14-21.

Received: October 13, 2014; Accepted: February 10, 2015. 